\title{
Effect of load current harmonics on vibration of three-phase generator
}

\author{
I Made Wiwit Kastawan ${ }^{1, *}$ \\ ${ }^{1}$ Politeknik Negeri Bandung, Department of Energy Conversion Engineering, Jl. Gegerkalong Hilir, Bandung Barat, Jawa Barat, \\ Indonesia
}

\begin{abstract}
Almost all today electrical loads are considered non-linear such as switch mode power supply (SMPS) for powering computer and mobile phone or variable speed drive (VSD) for driving home and industrial electric motors. These loads generate ac non-sinusoidal current containing a lot of harmonics as indicated by its high total harmonics distortion (THD) figure. Current harmonics bring negative effects into all electrical power system components, including three-phase generator. This paper provides analysis of load current harmonics effects on vibration of three-phase generator. Three different laboratory experiments have been conducted i.e. three-phase linear resistive loading, non-linear loading with a three-phase ac/dc converter and non-linear loading with three single-phase capacitor filtered ac/dc converters. Results show that the higher load current harmonics content the higher is vibration of the three-phase generator. Nonlinear loading with a three-phase ac/dc converter that generate about $24.7 \%$ THD gives an increase of $4.3 \%$ and $5.5 \%$ in average of vertical and horizontal vibrations of the three-phase generator respectively. Further, non-linear loading with three single-phase capacitor filtered ac/dc converters that generate THD as high as $74.9 \%$ gives significant increase of $28.1 \%$ and $23.6 \%$ in average of vertical and horizontal vibrations respectively.
\end{abstract}

\section{Introduction}

Nowadays, many electrical loads are classified as nonlinear such as switch mode power supply (SMPS) for powering computer as well as mobile phone and variable speed drive (VSD) for powering ac three-phase motor commonly used in water pump unit, compressor, belt conveyor, escalator and lift or robotic arms in an industrial production unit [1], [2], [3]. SMPS and VSD use single-phase ac/dc converter and three-phase ac/dc converter respectively at the input/ac side [4]. Switching of these converters produces ac non-sinusoidal current containing a lot of harmonics as indicated by the high total harmonic distortion figure (THDi). Current harmonics bring negative effects such as increasing power losses, reducing efficiency, increasing operating temperature and disoperation or even failure of many electrical power system components. Regarding its negative effects, methods are developed to reduce current harmonics. By operating converter in pulse width modulation modes, its current harmonics can be reduced significantly or even minimized [5], [6], [7]. Another method is using the phase shifting transformer to eliminate certain order harmonic currents [8].

Ac three-phase generator, hereinafter referred as generator, is a main electrical power system component. Generator producing electricity needed by all loads connected to an electrical power system [9]. Performance of a generator is mainly determined by current flowing in its three-phase armature windings. If a linear load is connected then harmonics free ac sinusoidal current will flow in generator three-phase armature windings. However, if a non-linear load is connected then ac non-sinusoidal current with harmonics will flow in generator three-phase armature windings. Obviously, generator performance differs on these two loading conditions. Effect of load current harmonics generated by non-linear loads on generator performance, particularly on its vibration, is investigated throughout this paper.

Vibration is one important parameter of generator operation. The others include voltage drop, power losses, efficiency and loading capacity. Vibration is frequently used as a parameter to identify condition of a turbinegenerator set [10]. When a generator operates or rotates, it will vibrate. A factor that determines how high a generator vibrates is its loading condition. Vibration on no-load condition differs to that on load condition [11], [12], [13]. Considering two loading conditions have been mentioned above, vibration of a generator on linear loading condition will be different to that on non-linear loading condition. Further, generator vibration on nonlinear loading differs according to current harmonics content generated by the non-linear load.

\footnotetext{
* Corresponding author: wiwit.kastawan@polban.ac.id
} 


\section{Laboratory experiments set up}

To investigate effect of current harmonics on generator vibration, three different laboratory experiments have been set up. The first one is linear loading with threephase resistive load. The second one is non-linear loading with a three-phase ac/dc converter and the last one is non-linear loading with three single-phase capacitor filtered ac/dc converters connected as perphase load of the three-phase generator output terminal. The aim of using these three kinds of load is to produce ac current with different harmonics content. Linear load supposed to produce ac sinusoidal current that contains no harmonics. Non-linear loading with a three-phase ac/dc converter will produce ac non-sinusoidal current that contains odd order harmonics except the triple ones. Finally, non-linear loading with three single-phase capacitor filtered ac/dc converters will produce ac nonsinusoidal current that contains all odd order harmonics [14].

Figure 1, Figure 2 and Figure 3 consecutively show the schematic diagrams of laboratory experiment of resistive linear loading, non-linear loading with a threephase ac/dc converter and non-linear loading with three single-phase capacitor filtered ac/dc converters.

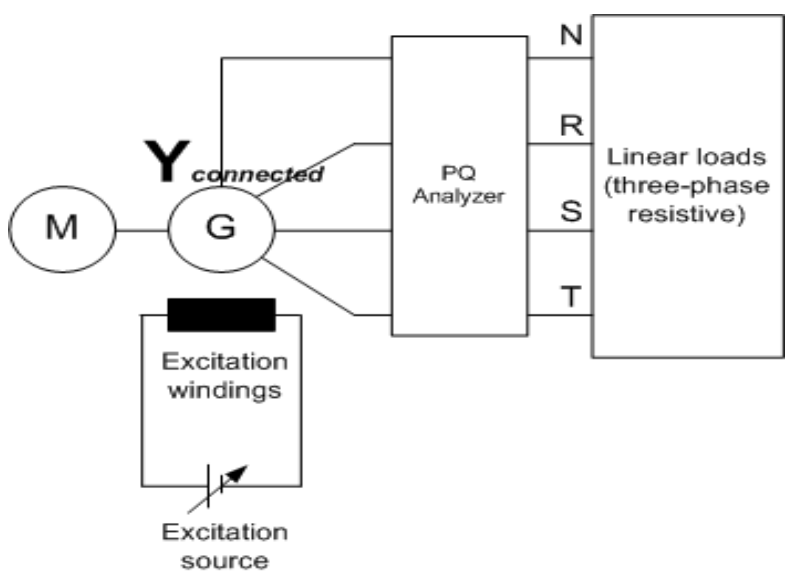

Fig. 1. Schematic diagram of laboratory experiment of resistive linear loading.

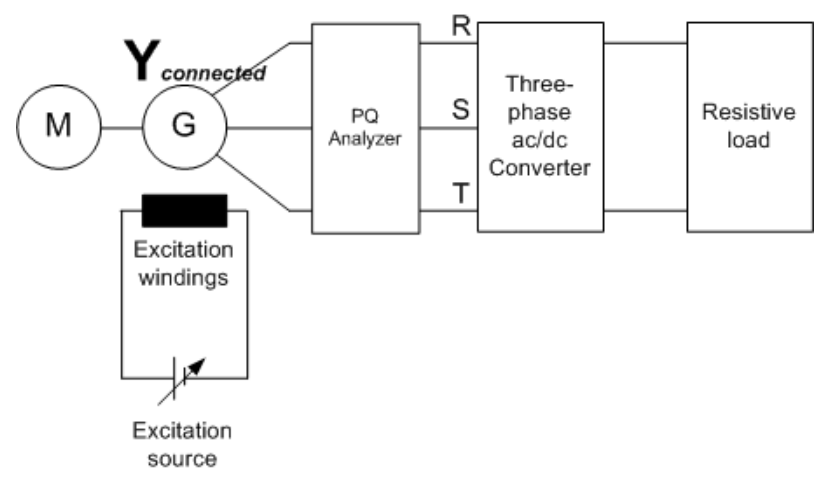

Fig. 2. Schematic diagram of laboratory experiment of nonlinear loading with a three-phase ac/dc converter.

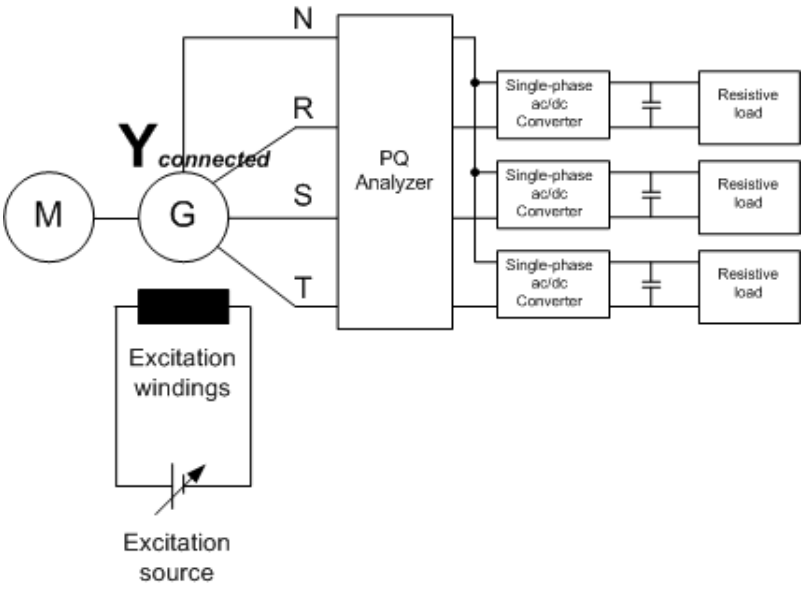

Fig. 3. Schematic diagram of laboratory experiment of nonlinear loading with three single-phase capacitor filtered ac/dc converters.

All three laboratory experiments above have similar operation procedure. It differs only on the type of load connected to three-phase output terminal of the generator. The generator is loaded step by step from noload to full load under constant shaft rotation and output voltage. Constant shaft rotation achieved by controlling speed of electric motor driver while constant output voltage achieved by controlling generator excitation current [9]. Power capacity of the generator is $5 \mathrm{~kW}$ with nominal phase to neutral output voltage of $220 \mathrm{~V}, 50 \mathrm{~Hz}$ at $3000 \mathrm{rpm}$ shaft rotation speed. The maximum load current is 7.4 A. Necessary data to be collected include load current magnitude, current harmonics contents (THDi) and generator vibration in vertical and horizontal directions. Magnitude and profile of load current are measured by Three-phase PQ Analyser while generator vibration is measured by Vibration Meter.

\section{Results and discussion}

Experiment in which generator is connected to threephase resistive load gives the data listed in Table 1 below. Value of load current $\left(I_{L}\right)$ measured is the effective (root mean square, rms) one. The effective fundamental value $\left(I_{L 1}\right)$ then determined by following equation [15]:

$$
I_{\mathrm{L}}=I_{\mathrm{L} 1}\left(1+\mathrm{THDi}^{2}\right)^{1 / 2}
$$

Figure 4 shows an example of generator load current waveform. It is shown that load current of $1.4 \mathrm{~A}$ has a harmonics content (THDi) of $13.3 \%$. Its spectrum then shows that only the third order harmonic emerges. Thus, generator load current is not an ideal harmonic free ac sinusoidal although the load connected is resistive linear. In average, the THDi figure of generator load current is about $17.6 \%$ when the load varies from 0 (no-load condition) to $7.1 \mathrm{~A}$. 
Table 1. Generator vibration on resistive linear loading condition.

\begin{tabular}{|c|c|c|c|}
\hline $\begin{array}{c}\text { Load } \\
\text { current, } \\
\boldsymbol{I}_{\boldsymbol{L}} \mathbf{( A )}\end{array}$ & $\begin{array}{c}\text { Fundamental } \\
\text { component of } \\
\text { load current, } \\
\boldsymbol{I}_{\boldsymbol{L} \boldsymbol{I}} \mathbf{( A )}\end{array}$ & $\begin{array}{c}\text { Vertical } \\
\text { vibration } \\
(\mathbf{m m} / \mathbf{s})\end{array}$ & $\begin{array}{c}\text { Horizontal } \\
\text { vibration } \\
\mathbf{( m m} / \mathbf{s})\end{array}$ \\
\hline 0.00 & 0.00 & 4.10 & 4.40 \\
\hline 1.40 & 1.38 & 4.90 & 5.60 \\
\hline 3.00 & 2.95 & 5.40 & 6.90 \\
\hline 4.40 & 4.33 & 5.80 & 8.90 \\
\hline 5.70 & 5.61 & 6.80 & 9.70 \\
\hline 7.10 & 6.99 & 7.70 & 10.50 \\
\hline
\end{tabular}
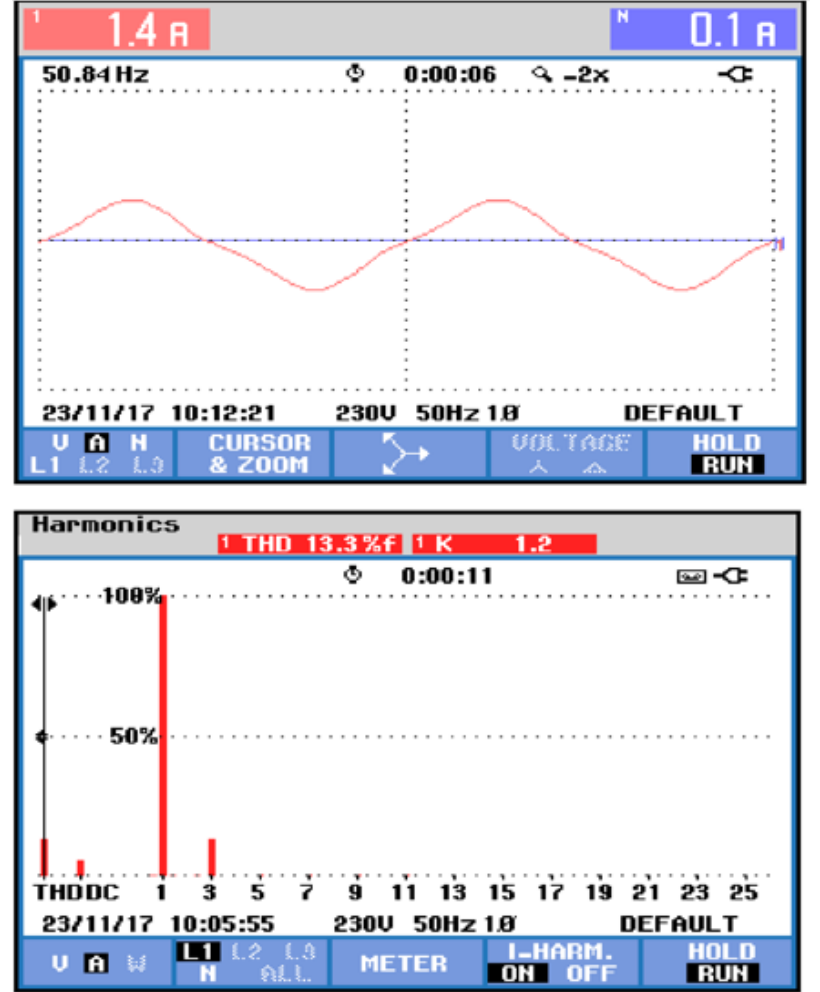

Fig. 4. Generator load current on resistive linear loading.

Data in Table 1 show that generator vibration both in vertical and horizontal directions increase when load increases. The data also show that generator vibration in horizontal direction is higher than in vertical direction. Figure 5 shows comparison between vertical and horizontal vibration of generator on resistive linear loading with THDi of $17.6 \%$ in average.

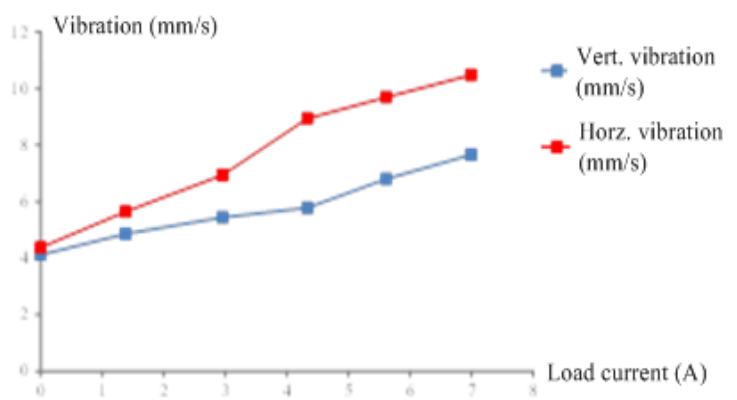

Fig. 5. Generator vibration on resistive linear loading with THDi of $17.6 \%$ in average.
Next, non-linear loading with a three-phase ac/dc converter gives the experimental data listed in Table 2 . Example of generator load current waveform in Figure 6 shows that it is ac non-sinusoidal with effective value of $1.4 \mathrm{~A}$ and THDi of $27.1 \%$. The current spectrum shows that it contains odd order harmonics except the triple ones i.e. the $5^{\text {th }}, 7^{\text {th }}, 11^{\text {th }}, 13^{\text {th }}$, and so on. However, only the $5^{\text {th }}$ and $7^{\text {th }}$ current harmonic orders have significant effective values as compared to effective value of fundamental component. In average, the THDi of generator load current reaches $24.7 \%$ when load varies from 0 to $5.1 \mathrm{~A}$.

Table 2. Generator vibration on non-linear loading with a three-phase ac/dc converter.

\begin{tabular}{|c|c|c|c|}
\hline $\begin{array}{c}\text { Load } \\
\text { current, } \\
\boldsymbol{I}_{\boldsymbol{L}} \mathbf{( A )}\end{array}$ & $\begin{array}{c}\text { Fundamental } \\
\text { component of } \\
\text { load current, } \\
\boldsymbol{I}_{\boldsymbol{L} \boldsymbol{I}} \mathbf{( A )}\end{array}$ & $\begin{array}{c}\text { Vertical } \\
\text { vibration } \\
(\mathbf{m m} / \mathbf{s})\end{array}$ & $\begin{array}{c}\text { Horizontal } \\
\text { vibration } \\
(\mathbf{m m} / \mathbf{s})\end{array}$ \\
\hline 0.00 & 0.00 & 4.10 & 4.40 \\
\hline 1.40 & 1.36 & 5.00 & 5.90 \\
\hline 2.70 & 2.62 & 5.60 & 6.80 \\
\hline 3.90 & 3.79 & 6.10 & 8.60 \\
\hline 5.10 & 4.95 & 6.70 & 9.70 \\
\hline
\end{tabular}
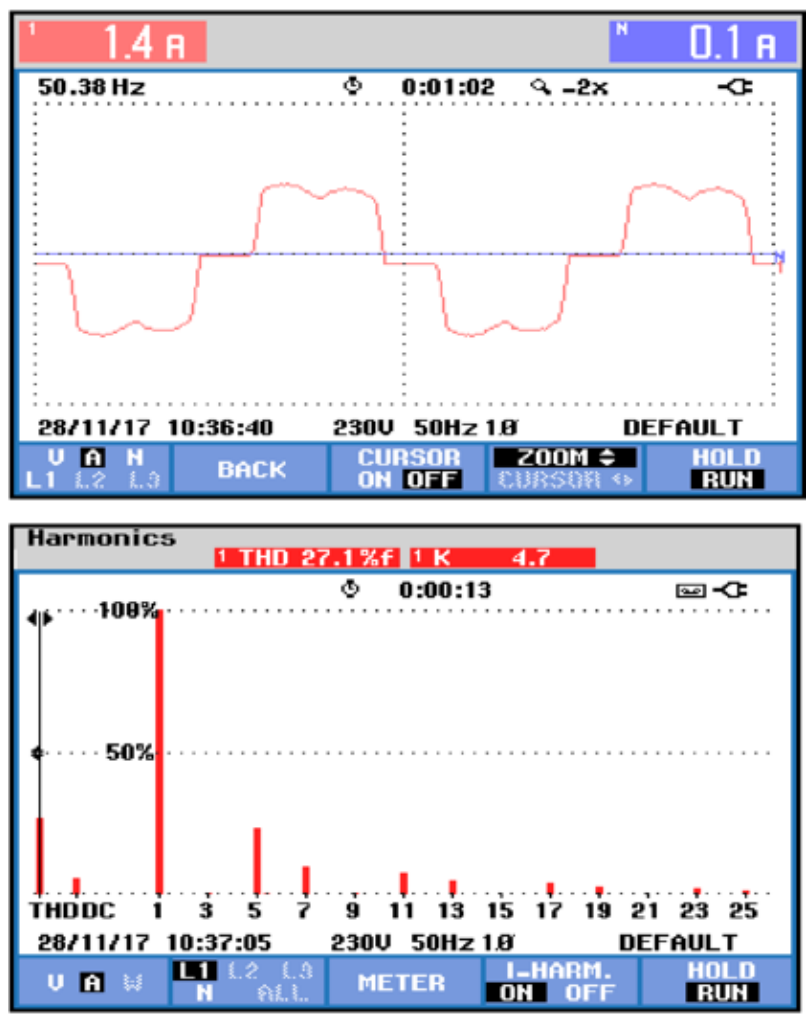

Fig. 6. Generator load current on non-linear loading with a three-phase ac/dc converter.

Again data in Table 2 show that both vertical and horizontal vibrations of the generator increase when load increases. Also, horizontal vibration of the generator is higher than that in vertical direction. Due to limitation of the available load, maximum generator load current on this non-linear loading is only 5.1 A or $69 \%$ of full load capacity. Figure 7 shows comparison between vertical and horizontal vibrations of generator on this non-linear loading condition with THDi of $24.7 \%$ in average. 


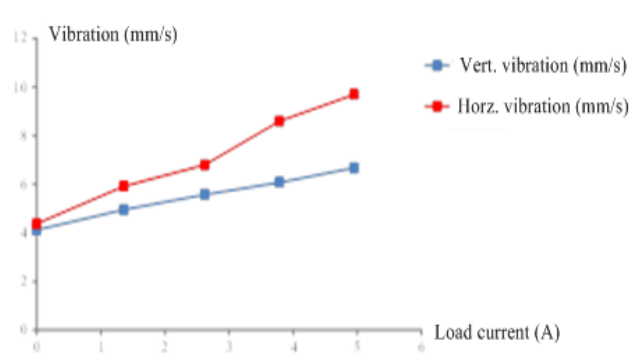

Fig. 7. Generator vibration on non-linear loading with THDi of $24.7 \%$ in average.

Last, non-linear loading with three single-phase capacitor filtered ac/dc converters gives the experimental data listed in Table 3. An example of generator load current waveform on this non-linear loading is shown in Figure 8. Clearly it is an ac non-sinusoidal current with effective value of $3.4 \mathrm{~A}$ and THDi of $77.5 \%$. The current spectrum shows that it contains all odd order harmonics i.e. the $3^{\text {rd }}, 5^{\text {th }}, 7^{\text {th }}, 9^{\text {th }}, 11^{\text {th }}, 13^{\text {th }}$, and so on in which the $3^{\text {rd }}, 5^{\text {th }}$ and $7^{\text {th }}$ become the most significant ones. In average, the THDi of generator load current reaches $74.9 \%$ when load varies from 0 to $6.6 \mathrm{~A}$.

Table 3. Generator vibration on non-linear loading with three single-phase capacitor filtered ac/dc converters.

\begin{tabular}{|c|c|c|c|}
\hline $\begin{array}{c}\text { Load } \\
\text { current, } \\
\boldsymbol{I}_{\boldsymbol{L}} \mathbf{( A )}\end{array}$ & $\begin{array}{c}\text { Fundamental } \\
\text { component of } \\
\text { load current, } \\
\boldsymbol{I}_{\boldsymbol{L} \boldsymbol{I}(\mathbf{A})}\end{array}$ & $\begin{array}{c}\text { Vertical } \\
\text { vibration } \\
\mathbf{( m m} / \mathbf{s})\end{array}$ & $\begin{array}{c}\text { Horizontal } \\
\text { vibration } \\
\mathbf{( m m} / \mathbf{s})\end{array}$ \\
\hline 0.00 & 0.00 & 4.10 & 4.40 \\
\hline 3.40 & 2.72 & 6.90 & 8.70 \\
\hline 6.60 & 5.28 & 8.60 & 11.60 \\
\hline
\end{tabular}
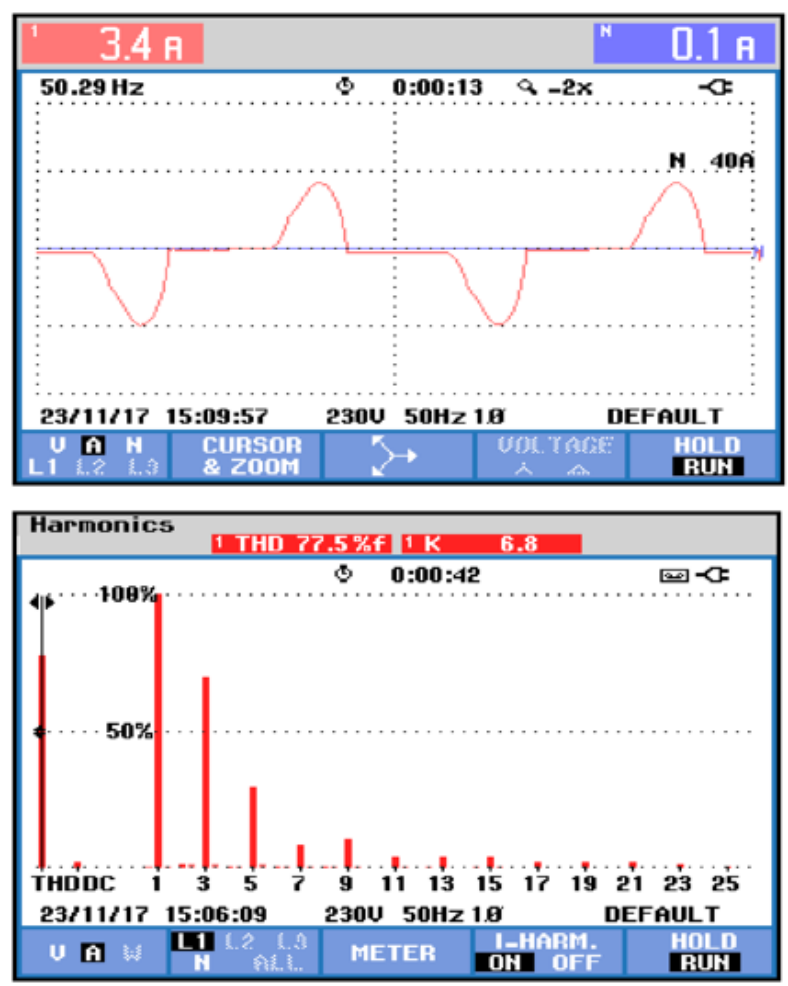

Fig. 8. Generator load current on non-linear loading with three single-phase capacitor filtered ac/dc converters.
Data in Table 3 shows that vertical and horizontal vibrations of the generator increase when load increases. The horizontal vibration is higher than vertical vibration. Similar to the previous non-linear loading experiment, generator cannot be fully loaded. The maximum load current is $6.6 \mathrm{~A}$ or $89 \%$ of full load capacity. Figure 9 shows comparison between vertical and horizontal vibrations of generator on this non-linear loading condition with THDi of $74.9 \%$ in average.

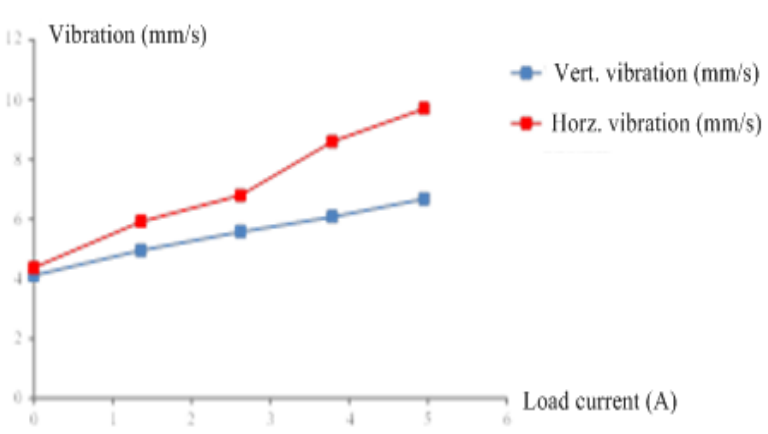

Fig. 9. Generator vibration on non-linear loading with THDi of $74.9 \%$ in average.

To investigate effect of load current harmonics on generator vibration, the vertical and horizontal vibrations of generator on those three different loading conditions have to be compared. Figure 10 shows comparison of the vertical vibration of generator on resistive linear loading, non-linear loading with a three-phase ac/dc converter (referred as non-linear loading\#1) with 24.7\% THDi and non-linear loading with three single-phase capacitor filtered ac/dc converters (referred as non-linear loading\#2) with $74.9 \%$ THDi. It is seen that the highest vertical vibration occurs when generator loaded by three single-phase capacitor filtered ac/dc converters while the lowest occurs when generator connected to resistive linear load. Thus, the higher current harmonics content the higher vertical vibration of generator.

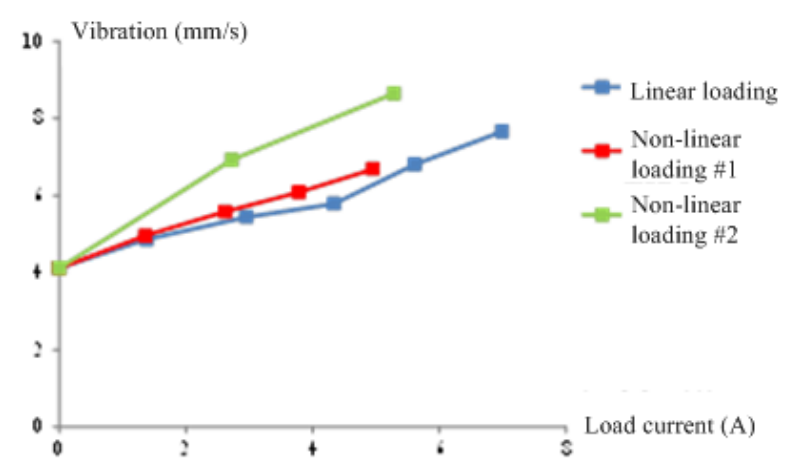

Fig. 10. Comparison of the vertical vibration of generator on three different loading conditions.

Next, Figure 11 shows comparison of the vertical vibration of generator on those three different loading conditions for same load current magnitude. It can be seen that the vertical vibration of generator increases about $4.3 \%$ in average and $28.1 \%$ in average respectively 
when it loaded by non-linear load with $24.7 \%$ THDi and $74.9 \%$ THDi as compared to resistive linear loading with $17.6 \%$ THDi.

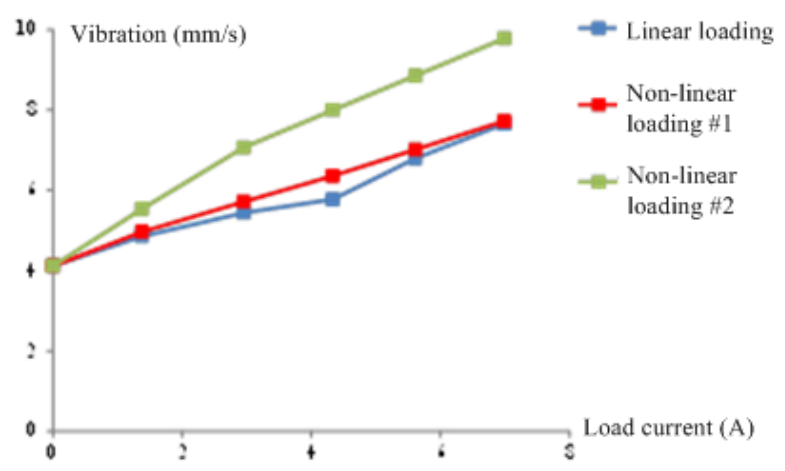

Fig. 11. Comparison of the vertical vibration of generator on three different loading conditions for same load current magnitude.

Meanwhile, Figure 12 shows comparison of the horizontal vibration of generator on those three different loading conditions. Again it is shown that the highest horizontal vibration occurs when generator is loaded by three single-phase capacitor filtered ac/dc converters while the lowest occurs when the generator is connected to resistive linear load. Thus, the higher current harmonics content the higher horizontal vibration of generator.

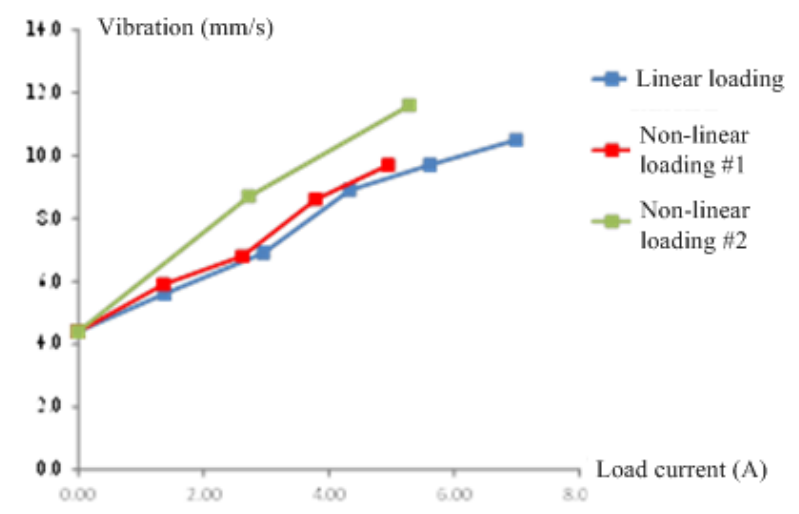

Fig. 12. Comparison of the horizontal vibration of generator on three different loading conditions.

In Figure 13, the horizontal vibration of generator on those three different loading conditions for same load current magnitude is shown. It can be seen that the horizontal vibration of generator increases about $5.5 \%$ in average and $23.6 \%$ in average respectively when it loaded by non-linear load with $24.7 \%$ THDi and $74.9 \%$ THDi as compared to resistive linear loading with $17.6 \%$ THDi.

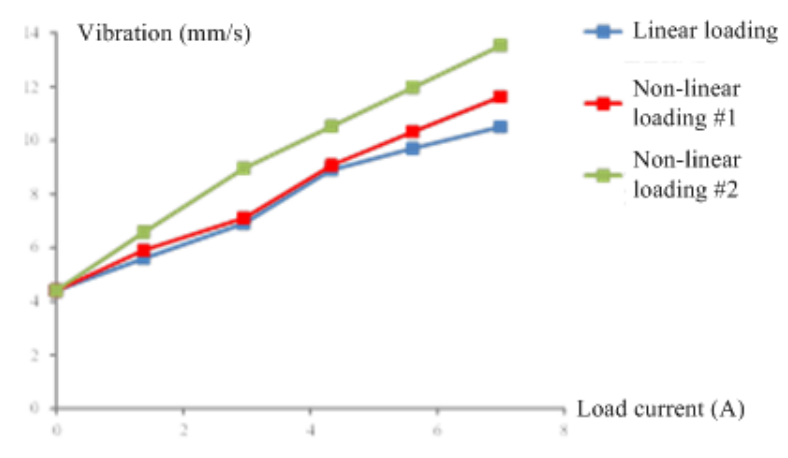

Fig. 13. Comparison of the horizontal vibration of generator on three different loading conditions for same load current magnitude.

\section{Conclusions}

Loading condition strongly determines generator vibration. Higher load results in higher generator vibration. Also the higher harmonics contents of the load, the higher is vibration of the generator. Results from laboratory experiment show that non-linear loading with a three-phase ac/dc converter that has about $24.7 \%$ THDi in average gives an increase of $4.3 \%$ in vertical vibration and $5.5 \%$ in horizontal vibration as compared to linear loading with about $17.6 \%$ THDi in average. Further, non-linear loading with three single-phase capacitor filtered ac/dc converter that has about $74.9 \%$ THDi in average gives an increase of $28.1 \%$ in vertical vibration and $23.6 \%$ in horizontal vibration as compared to linear loading with about $17.6 \%$ THDi in average.

The author would like to thank Politeknik Negeri Bandung for providing fund for this research through scheme of Penelitian Mandiri 2017.

\section{References}

1. D. N. Huda, Pengujian Unjuk Kerja Variable Speed Drive VF-S9 Dengan Beban Motor Induksi TigaFasa 1 HP, (Program Studi D-3 Teknik Listrik Jurusan Teknik Elektro, Politeknik Negeri Bandung, Bandung, 2015)

2. S. Nasution, Analisis Sistem Kerja Inverter untuk Mengubah Kecepatan Motor Induksi Tiga Phasa sebagai Driver Robot, J. Ilmiah Elite Elektro, Vol. 3, No. 2, (2012)

3. F. M. Wildan, E. A. Hakim, D. Suhardi, Sistem Pengaturan Kecepatan Motor Induksi Tiga Fasa Menggunakan Kontroler PID Berbasis Genetic Algorithm, J. Kinetik, Vol.1, No.1, (2016)

4. D. Salomonsson, Low-Voltage DC Distribution System for Commercial Power Systems With Sensitive Electronics Loads, IEEE Transactions on Power Delivery, Vol. 22, No. 3, July (2007)

5. M. A. Patel, A. R. Patel, D. R. Vyas, K. M. Patel, Use of PWM Techniques for Power Quality 
Improvement, Int. J. of Recent Trends in Engineering, Vol. 1, No. 4, May (2009)

6. J. Holtz, Pulsewidth Modulation for Electronic Power Conversion, Proceedings of IEEE, Vol. 82 No. 8, Aug (1994)

7. J. R. Wells, B. M. Nee, P. L. Chapman, P. T. Krein, Optimal Harmonic Elimination Control, $35^{\text {th }}$ Annual IEEE Power Electronics Specialists Conference, (2004)

8. R. Omar, A. Ahmad, M. Sulaiman, Triplen Harmonics Mitigation 3 Phase Four-Wire Electrical Distribution System Using Wye-Zig-Zag Transformers, J. of Emerging Trends in Eng. and Appl. Sci. (JETEAS) 1 (1), (2010)

9. B. L. Theraja, A. K. Theraja, A Textbook of Electrical Technology in SI Units Volume II AC and DC Machines, S. Chand Publisher, (2013)

10. D. Miljkovic, Brief Review of Vibration Based Machine Condition Monitoring, (Hrvatska Elektroprivreda, Zagreb, Croatia, 2016)

11. B. Cahyono, D. Priyanta, F. Rizqullah, F. Ramadhan, Vibration Spectrum Analysis for Indicating Damage on Turbine and Steam Generator Amurang Unit 1, Int. J. of Marine Engineering Innovation and Research, Vol. 2, No. 1, Dec. (2017)

12. P. Kumar B. K., Y. Basavaraj, Nandeesh C., Vibration Based Condition Monitoring for Generator, Int. J. of Research in Engineering Technology, Vol. 4, No. 6, Jun (2016)

13. C. Hatiegan, I. Padureanu, M. Jurcu, M. D. Nedeloni, et al., Vibration Analysis of A Hydro Generator for Different Operating Regimes, International Conference on Applied Sciences (ICAS2016), IOP Conf. Series: Material Science and Engineering 163 (2017)

14. M. H. Rashid, Power Electronics Handbook and Applications (Elsevier-BH, 2011)

15. Paul Gill, Electrical Power Equipment, Maintenance and Testing, Second Edition, (CRC Press, 2009) 